\title{
Optimization of a Multiple Injection System in a Marine Diesel Engine through a Multiple-Criteria Decision-Making Approach
}

\author{
Maria Isabel Lamas ${ }^{1, *(\mathbb{D})}$, Laura Castro-Santos ${ }^{1}\left[\right.$ and Carlos G. Rodriguez ${ }^{2}$ \\ 1 Higher Polytechnic University College, University of Coruña, 15403 Ferrol, Spain; laura.castro.santos@udc.es \\ 2 Norplan Engineering S.L., 15570 Naron, Spain; c.rodriguez.vidal@udc.es \\ * Correspondence: isabellamas@udc.es; Tel.: +34-881-013-896
}

Received: 25 October 2020; Accepted: 18 November 2020; Published: 20 November 2020

check for updates

\begin{abstract}
In this work, a numerical model was developed to analyze the performance and emissions of a marine diesel engine, the Wärtsilä $6 \mathrm{~L} 46$. This model was validated using experimental measurements and was employed to analyze several pre-injection parameters such as pre-injection rate, duration, and starting instant. The modification of these parameters may lead to opposite effects on consumption and/or emissions of nitrogen oxides $\left(\mathrm{NO}_{\mathrm{x}}\right)$, carbon monoxide $(\mathrm{CO})$, and hydrocarbons $(\mathrm{HC})$. According to this, the main goal of the present work is to employ a multiple-criteria decision-making (MCDM) approach to characterize the most appropriate injection pattern. Since determining the criteria weights significantly influences the overall result of a MCDM problem, a subjective weighting method was compared with four objective weighting methods: entropy, CRITIC (CRiteria Importance Through Intercriteria Correlation), variance, and standard deviation. The results showed the importance of subjectivism over objectivism in MCDM analyses. The CRITIC, variance, and standard deviation methods assigned more importance to $\mathrm{NO}_{\mathrm{x}}$ emissions and provided similar results. Nevertheless, the entropy method assigned more importance to consumption and provided a different injection pattern.
\end{abstract}

Keywords: MCDM; marine engine; injection; emissions; consumption

\section{Introduction}

Pollution levels in recent years have been reaching dangerous limits. Important contributors to global pollution are diesel engines, which are efficient machines but emit important levels of particulate matter (PM), $\mathrm{NO}_{x}, \mathrm{CO}_{2}, \mathrm{CO}, \mathrm{HC}, \mathrm{SO}_{\mathrm{x}}$, etc. [1-5]. Between these, $\mathrm{NO}_{\mathrm{x}}$ and $\mathrm{SO}_{\mathrm{x}}$ are characteristic of marine diesel engines [6-10]. According to the International Maritime Organization (IMO), $\mathrm{NO}_{\mathrm{x}}$ and $\mathrm{SO}_{\mathrm{x}}$ from ships represent $5 \%$ and $13 \%$ of global $\mathrm{NO}_{\mathrm{x}}$ and $\mathrm{SO}_{\mathrm{x}}$ emissions, respectively [11]. IMO regulates $\mathrm{NO}_{x}$ and $\mathrm{SO}_{\mathrm{x}}$ in the shipping sector. Regarding $\mathrm{SO}_{x}$, since the sulfur content of the fuel is the reason for $\mathrm{SO}_{\mathrm{x}}$ emission, IMO limits the sulfur content of fuels or requires the use of exhaust gas cleaning systems to reduce sulfur emissions [12]. Regarding $\mathrm{NO}_{\mathrm{x}}$, IMO imposes even increasing limitations. According to this, several $\mathrm{NO}_{x}$ reduction procedures have been developed in recent years. Some of them, called primary measurements, operate on the engine performance, such as EGR, water injection, modification of the injection parameters, etc. On the other hand, other $\mathrm{NO}_{\mathrm{x}}$ reduction procedures, called secondary measurements, remove this pollutant from exhaust gases by downstream cleaning techniques, such as selective catalytic reduction (SCR). The present work focuses on pre-injection systems. It is well known that pilot injections reduce $\mathrm{NO}_{x}$ noticeably [13-17], but sometimes pilot injections can increase consumption and other pollutants such as smoke or hydrocarbons (HC) [18-22], mainly depending on parameters such as injection time, duration, number of pre-injections, dwelling time, etc. Since these 
parameters provide conflicting results, a formal tool to establish the most appropriate injection pattern is necessary. According to this, multiple-criteria decision-making (MCDM) approaches constitute a formal tool for handling complex decision-making problems. MCDM methods are complex decision-making tools for choosing the optimal option in cases where there are conflicting criteria. Since the start of the MCDM methods in the 1960s, they were employed in many fields such as sustainability, supply chain management, materials, quality management, GIS, construction and project management, safety and risk management, manufacturing systems, technology, information management, soft computing, tourism management, etc. [23]. One of the handicaps of MCDM methods is the determination of the criteria weights, i.e., the degree of importance for each criterion. It is important to focus on the criteria weights due to their influence on the overall result. According to this, several approaches to define the criteria weights can be found in the literature. Briefly, these approaches can be divided into subjective, i.e., based on the estimations of experts, and objective, i.e., calculated through mathematical expressions. In practice, subjective weights are most commonly used [24]. Contrary to subjective methods, the objective weights are based on mathematical methods and decision-makers have no role in determining the relative importance of criteria. Common objective methods are entropy [25], CRITIC [26], standard deviation [27], variance, mean weight, etc.

The present paper proposes a MCDM approach to select the most appropriate injection pattern using a pilot injection in the marine diesel engine Wärtsilä 6L 46. The pre-injection rate, duration, and starting instants were analyzed and the criteria were specific fuel consumption (SFC) and $\mathrm{NO}_{x}, \mathrm{CO}$, and HC emissions. These emissions and consumption were characterized through CFD (Computational Fluid Dynamics) analyses. Due to the importance of the criteria weights on the overall result, a comparison of several weighting methods was realized. A subjective criteria weighting method was compared to four objective criteria weighting methods: entropy, CRITIC, variance, and standard deviation.

\section{Materials and Methods}

The Wärtsilä 6L 46 is a four-stroke marine diesel engine, turbocharged and intercooled with direct fuel injection. It has 6 in-line cylinders and each cylinder has 2 inlet and 2 exhaust valves. The standard engine employed in the present work does not implement any $\mathrm{NO}_{x}$ reduction system such as water injection, EGR, SCR, etc. It incorporates a fast and efficient turbocharging system called single pipe exhaust (SPEX). The cooling system is split into high-temperature and low-temperature stages. Other specifications are provided in Table 1.

Table 1. Characteristics of the engine at $100 \%$ load.

\begin{tabular}{cc}
\hline Parameter & Value \\
\hline Output & $5430 \mathrm{~kW}$ \\
Speed & $500 \mathrm{rpm}$ \\
Piston displacement & $96.4 \mathrm{~L} / \mathrm{cyl}$ \\
Bore & $460 \mathrm{~mm}$ \\
Stroke & $580 \mathrm{~mm}$ \\
Speed & $500 \mathrm{rpm}$ \\
Mean effective pressure & $22.5 \mathrm{bar}$ \\
Mean piston speed & $9.7 \mathrm{~m} / \mathrm{s}$ \\
\hline
\end{tabular}

A CFD analysis previously validated with experimental results [28-34] was carried out using the open software OpenFOAM. The simulation was based on the equations of conservation of mass, momentum, and energy and the numerical details are listed in Table 2. 
Table 2. Numerical details.

\begin{tabular}{cc}
\hline Parameter & Model \\
\hline Turbulence model & k- $\varepsilon$ \\
Combustion kinetic scheme & Ra and Reitz [35] (131 reactions and 41 species) \\
$\mathrm{NO}_{\mathbf{x}}$ formation kinetic scheme & Yang et al. [36] (43 reactions and 20 species) \\
$\mathrm{NO}_{\mathrm{x}}$ reduction kinetic scheme & Miller and Glarborg [37] (131 reactions and 24 species) \\
Fuel heat-up and evaporation model & Dukowicz [38] \\
Fuel droplet breakup model & Kelvin-Helmholtz and Rayleigh-Taylor [39] \\
\hline
\end{tabular}

A comparison between the numerical and experimental results is illustrated in Figure 1 and Figure 2. Figure 1 shows the emissions and SFC obtained numerically and experimentally at several loads, and Figure 2 shows the in-cylinder pressure and heat release rate obtained numerically and experimentally at $100 \%$ load. As can be seen, both figures show a reasonable correspondence between numerical and experimental results.

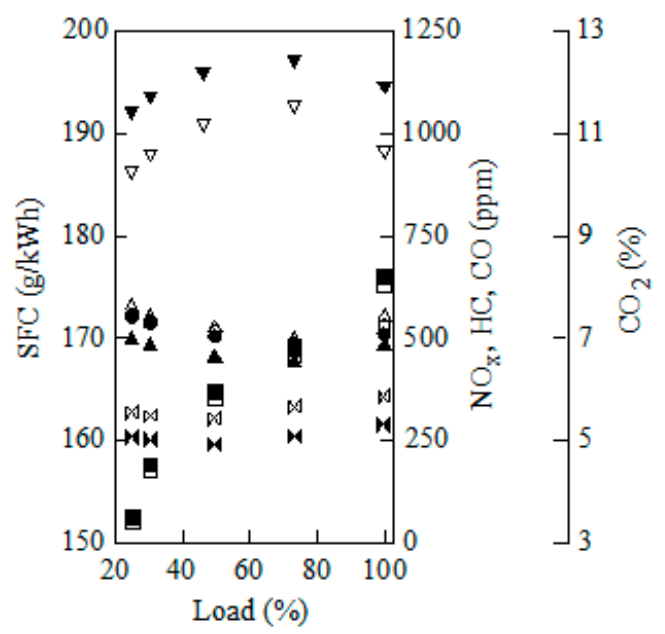

- SFC, experimental

- $\mathrm{NO}_{\mathrm{x}}$, experimental

^ HC, experimental

$\mathrm{CO}$, experimental

- $\mathrm{CO}_{2}$, experimental

o $\mathrm{SFC}$, numerical

$\nabla \mathrm{NO}_{\mathrm{x}}$, numerical

$\triangle \mathrm{HC}$, numerical

$\triangle \mathrm{CO}$, numerical

$\square \mathrm{CO}_{2}$, numerical

Figure 1. Specific fuel consumption (SFC) and emissions numerically and experimentally obtained at different loads.

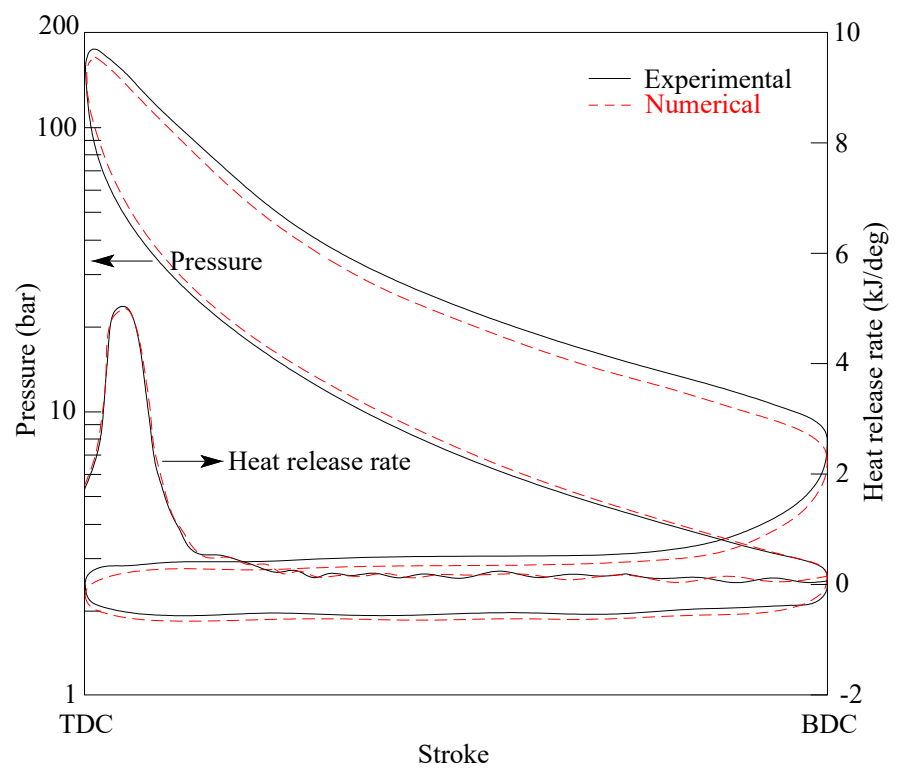

Figure 2. In-cylinder pressure numerically and experimentally obtained at $100 \%$ load. 


\section{Results and Discussion}

Once validated, this CFD model was used to provide the data for the MCDM approach. The simulation calculation was carried out simply as a process and as sample results for applying the optimal selection method of multiple injection conditions. The 125 cases illustrated in Figure 3 were analyzed. As can be seen, five pre-injection rates (R): $5 \%, 10 \%, 15 \%, 20 \%$, and $25 \%$; five pre-injection durations (D): $1^{\circ}, 2^{\circ}, 3^{\circ}, 4^{\circ}$, and $5^{\circ}$ crank angle (CA); and five pre-injection starting instants (S): $-22^{\circ}$, $-21^{\circ},-20^{\circ},-19^{\circ}$, and $-18^{\circ}$ crank angle after top dead center (CA ATDC), were employed.

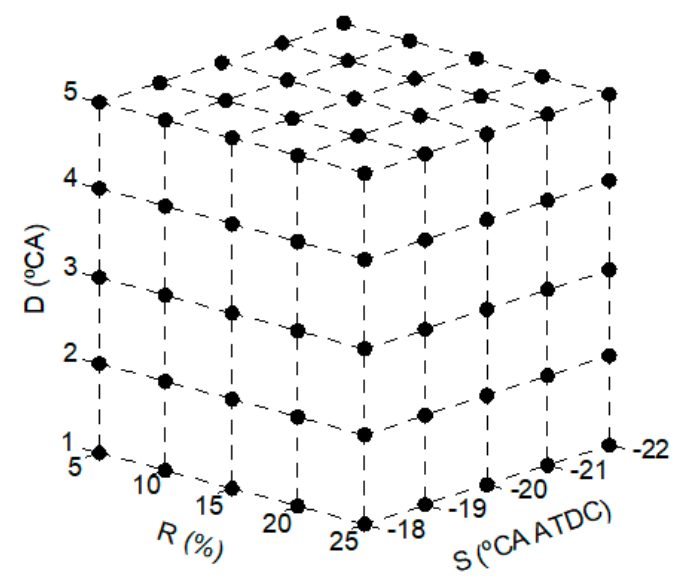

Figure 3. Illustration of the 125 cases analyzed.

Four criteria were analyzed: $\mathrm{SFC}, \mathrm{NO}_{\mathrm{x}}, \mathrm{CO}$, and $\mathrm{HC}$. It is worth mentioning that $\mathrm{PM}$ emissions should be included in this model. They were not included because current numerical methods do not provide enough accuracy regarding PM [40]. Nevertheless, continuous efforts are being made to develop more models which will provide proper accuracy in the near future.

Table 3 outlines the pre-injection rate, duration, and starting instant, as well as the values of SFC, $\mathrm{NO}_{\mathrm{x}}, \mathrm{CO}$, and $\mathrm{HC}$ provided by the CFD model for the 125 cases. According to this, the data matrix is composed of 125 rows and 4 columns. In the remaining of the present work, each datum of the decision matrix will be represented as $X_{i j}$, where $i$ is the case and $j$ is the criteria considered.

Table 3. Data for the multiple-criteria decision-making (MCDM) problem.

\begin{tabular}{|c|c|c|c|c|c|c|c|}
\hline \multirow[b]{2}{*}{ Case (i) } & \multirow[b]{2}{*}{$\begin{array}{c}\mathrm{S} \\
\left({ }^{\circ} \mathrm{CA} \text { ATDC) }\right.\end{array}$} & \multirow[b]{2}{*}{$\begin{array}{c}R \\
(\%)\end{array}$} & \multirow[b]{2}{*}{$\begin{array}{c}D \\
\left({ }^{\circ} \mathrm{CA}\right)\end{array}$} & \multicolumn{4}{|c|}{ Criterion $(j)$} \\
\hline & & & & $\begin{array}{c}j=1 \\
\mathrm{SFC}(\mathrm{g} / \mathrm{kWh})\end{array}$ & $\begin{array}{c}j=2 \\
\mathrm{NO}_{\mathrm{x}}(\mathrm{g} / \mathrm{kWh})\end{array}$ & $\begin{array}{c}j=3 \\
\mathrm{CO}(\mathrm{g} / \mathrm{kWh})\end{array}$ & $\begin{array}{c}j=4 \\
\text { HC (g/kWh) }\end{array}$ \\
\hline 1 & -22 & 5 & 1 & 190.9 & 7.38 & 4.65 & 5.72 \\
\hline 2 & -22 & 5 & 2 & 189.0 & 7.83 & 4.67 & 5.73 \\
\hline 3 & -22 & 5 & 3 & 187.5 & 8.19 & 4.70 & 5.76 \\
\hline 4 & -22 & 5 & 4 & 186.6 & 8.43 & 4.74 & 5.80 \\
\hline 5 & -22 & 5 & 5 & 186.1 & 8.58 & 4.78 & 5.84 \\
\hline 6 & -22 & 10 & 1 & 196.4 & 6.01 & 4.70 & 5.78 \\
\hline 7 & -22 & 10 & 2 & 193.9 & 6.57 & 4.73 & 5.81 \\
\hline 8 & -22 & 10 & 3 & 192.1 & 7.00 & 4.77 & 5.84 \\
\hline 9 & -22 & 10 & 4 & 190.8 & 7.31 & 4.81 & 5.89 \\
\hline 10 & -22 & 10 & 5 & 190.2 & 7.49 & 4.86 & 5.94 \\
\hline 11 & -22 & 15 & 1 & 200.4 & 5.06 & 4.74 & 5.83 \\
\hline 12 & -22 & 15 & 2 & 197.5 & 5.70 & 4.77 & 5.86 \\
\hline 13 & -22 & 15 & 3 & 195.3 & 6.19 & 4.81 & 5.90 \\
\hline 14 & -22 & 15 & 4 & 193.9 & 6.53 & 4.86 & 5.95 \\
\hline 15 & -22 & 15 & 5 & 193.1 & 6.73 & 4.92 & 6.02 \\
\hline 16 & -22 & 20 & 1 & 203.6 & 4.32 & 4.77 & 5.87 \\
\hline 17 & -22 & 20 & 2 & 200.3 & 5.01 & 4.80 & 5.90 \\
\hline
\end{tabular}


Table 3. Cont.

\begin{tabular}{|c|c|c|c|c|c|c|c|}
\hline \multirow[b]{2}{*}{ Case (i) } & \multirow{2}{*}{$\begin{array}{c}\text { S } \\
\left({ }^{\circ} \text { CA ATDC) }\right.\end{array}$} & \multirow{2}{*}{$\begin{array}{c}R \\
(\%)\end{array}$} & \multirow{2}{*}{$\begin{array}{c}\text { D } \\
\left({ }^{\circ} \mathrm{CA}\right)\end{array}$} & \multicolumn{4}{|c|}{ Criterion $(j)$} \\
\hline & & & & $\begin{array}{c}j=1 \\
\mathrm{SFC}(\mathrm{g} / \mathrm{kWh})\end{array}$ & $\begin{array}{c}j=2 \\
\mathrm{NO}_{\mathrm{x}}(\mathrm{g} / \mathrm{kWh})\end{array}$ & $\begin{array}{c}j=3 \\
\mathrm{CO}(\mathrm{g} / \mathrm{kWh})\end{array}$ & $\begin{array}{c}j=4 \\
\text { HC (g/kWh) }\end{array}$ \\
\hline 18 & -22 & 20 & 3 & 197.9 & 5.55 & 4.85 & 5.94 \\
\hline 19 & -22 & 20 & 4 & 196.3 & 5.92 & 4.91 & 6.00 \\
\hline 20 & -22 & 20 & 5 & 195.5 & 6.14 & 4.97 & 6.07 \\
\hline 21 & -22 & 25 & 1 & 206.3 & 3.70 & 4.79 & 5.90 \\
\hline 22 & -22 & 25 & 2 & 202.8 & 4.44 & 4.83 & 5.93 \\
\hline 23 & -22 & 25 & 3 & 200.2 & 5.01 & 4.88 & 5.98 \\
\hline 24 & -22 & 25 & 4 & 198.4 & 5.41 & 4.94 & 6.05 \\
\hline 25 & -22 & 25 & 5 & 197.5 & 5.65 & 5.02 & 6.13 \\
\hline 26 & -21 & 5 & 1 & 185.2 & 8.65 & 4.62 & 5.68 \\
\hline 27 & -21 & 5 & 2 & 183.3 & 9.11 & 4.65 & 5.70 \\
\hline 28 & -21 & 5 & 3 & 181.9 & 9.46 & 4.67 & 5.72 \\
\hline 29 & -21 & 5 & 4 & 180.9 & 9.71 & 4.71 & 5.76 \\
\hline 30 & -21 & 5 & 5 & 180.4 & 9.85 & 4.75 & 5.80 \\
\hline 31 & -21 & 10 & 1 & 189.1 & 7.57 & 4.67 & 5.73 \\
\hline 32 & -21 & 10 & 2 & 186.6 & 8.14 & 4.69 & 5.76 \\
\hline 33 & -21 & 10 & 3 & 184.7 & 8.57 & 4.73 & 5.79 \\
\hline 34 & -21 & 10 & 4 & 183.5 & 8.88 & 4.77 & 5.84 \\
\hline 35 & -21 & 10 & 5 & 182.9 & 9.05 & 4.83 & 5.89 \\
\hline 36 & -21 & 15 & 1 & 191.9 & 6.83 & 4.70 & 5.77 \\
\hline 37 & -21 & 15 & 2 & 189.0 & 7.47 & 4.73 & 5.80 \\
\hline 38 & -21 & 15 & 3 & 186.8 & 7.96 & 4.77 & 5.84 \\
\hline 39 & -21 & 15 & 4 & 185.4 & 8.31 & 4.82 & 5.89 \\
\hline 40 & -21 & 15 & 5 & 184.6 & 8.51 & 4.88 & 5.96 \\
\hline 41 & -21 & 20 & 1 & 194.1 & 6.25 & 4.72 & 5.81 \\
\hline 42 & -21 & 20 & 2 & 190.9 & 6.94 & 4.76 & 5.84 \\
\hline 43 & -21 & 20 & 3 & 188.5 & 7.48 & 4.80 & 5.88 \\
\hline 44 & -21 & 20 & 4 & 186.9 & 7.86 & 4.86 & 5.94 \\
\hline 45 & -21 & 20 & 5 & 186.1 & 8.07 & 4.93 & 6.01 \\
\hline 46 & -21 & 25 & 1 & 196.0 & 5.76 & 4.74 & 5.83 \\
\hline 47 & -21 & 25 & 2 & 192.5 & 6.50 & 4.78 & 5.87 \\
\hline 48 & -21 & 25 & 3 & 189.9 & 7.08 & 4.83 & 5.91 \\
\hline 49 & -21 & 25 & 4 & 188.1 & 7.48 & 4.89 & 5.98 \\
\hline 50 & -21 & 25 & 5 & 187.3 & 7.71 & 4.97 & 6.06 \\
\hline 51 & -20 & 5 & 1 & 181.2 & 9.61 & 4.60 & 5.65 \\
\hline 52 & -20 & 5 & 2 & 179.3 & 10.07 & 4.62 & 5.67 \\
\hline 53 & -20 & 5 & 3 & 177.9 & 10.42 & 4.65 & 5.69 \\
\hline 54 & -20 & 5 & 4 & 176.9 & 10.67 & 4.68 & 5.73 \\
\hline 55 & -20 & 5 & 5 & 176.4 & 10.81 & 4.73 & 5.77 \\
\hline 56 & -20 & 10 & 1 & 183.9 & 8.76 & 4.64 & 5.69 \\
\hline 57 & -20 & 10 & 2 & 181.4 & 9.32 & 4.66 & 5.72 \\
\hline 58 & -20 & 10 & 3 & 179.6 & 9.75 & 4.70 & 5.75 \\
\hline 59 & -20 & 10 & 4 & 178.3 & 10.06 & 4.74 & 5.80 \\
\hline 60 & -20 & 10 & 5 & 177.7 & 10.24 & 4.80 & 5.85 \\
\hline 61 & -20 & 15 & 1 & 185.9 & 8.17 & 4.66 & 5.73 \\
\hline 62 & -20 & 15 & 2 & 183.0 & 8.81 & 4.69 & 5.75 \\
\hline 63 & -20 & 15 & 3 & 180.8 & 9.30 & 4.74 & 5.79 \\
\hline 64 & -20 & 15 & 4 & 179.3 & 9.64 & 4.79 & 5.85 \\
\hline 65 & -20 & 15 & 5 & 178.6 & 9.84 & 4.85 & 5.91 \\
\hline 66 & -20 & 20 & 1 & 187.4 & 7.71 & 4.68 & 5.75 \\
\hline 67 & -20 & 20 & 2 & 184.2 & 8.40 & 4.72 & 5.78 \\
\hline 68 & -20 & 20 & 3 & 181.8 & 8.93 & 4.76 & 5.83 \\
\hline 69 & -20 & 20 & 4 & 180.2 & 9.31 & 4.82 & 5.89 \\
\hline 70 & -20 & 20 & 5 & 179.4 & 9.53 & 4.89 & 5.96 \\
\hline 71 & -20 & 25 & 1 & 188.8 & 7.32 & 4.70 & 5.78 \\
\hline 72 & -20 & 25 & 2 & 185.3 & 8.06 & 4.74 & 5.81 \\
\hline 73 & -20 & 25 & 3 & 182.6 & 8.63 & 4.79 & 5.86 \\
\hline 74 & -20 & 25 & 4 & 180.9 & 9.04 & 4.85 & 5.92 \\
\hline
\end{tabular}


Table 3. Cont.

\begin{tabular}{|c|c|c|c|c|c|c|c|}
\hline \multirow[b]{2}{*}{ Case (i) } & \multirow{2}{*}{$\begin{array}{c}\text { S } \\
\left({ }^{\circ} \text { CA ATDC) }\right.\end{array}$} & \multirow{2}{*}{$\begin{array}{l}R \\
(\%)\end{array}$} & \multirow{2}{*}{$\begin{array}{c}\mathrm{D} \\
\left({ }^{\circ} \mathrm{CA}\right)\end{array}$} & \multicolumn{4}{|c|}{ Criterion $(j)$} \\
\hline & & & & $\begin{array}{c}j=1 \\
\mathrm{SFC}(\mathrm{g} / \mathrm{kWh})\end{array}$ & $\begin{array}{c}j=2 \\
\mathrm{NO}_{x}(\mathrm{~g} / \mathrm{kWh})\end{array}$ & $\begin{array}{c}j=3 \\
\mathrm{CO}(\mathrm{g} / \mathrm{kWh})\end{array}$ & $\begin{array}{c}j=4 \\
\mathrm{HC}(\mathrm{g} / \mathrm{kWh})\end{array}$ \\
\hline 75 & -20 & 25 & 5 & 180.0 & 9.27 & 4.93 & 6.00 \\
\hline 76 & -19 & 5 & 1 & 178.9 & 10.26 & 4.59 & 5.62 \\
\hline 77 & -19 & 5 & 2 & 177.0 & 10.71 & 4.61 & 5.64 \\
\hline 78 & -19 & 5 & 3 & 175.5 & 11.07 & 4.63 & 5.67 \\
\hline 79 & -19 & 5 & 4 & 174.6 & 11.32 & 4.67 & 5.70 \\
\hline 80 & -19 & 5 & 5 & 174.1 & 11.46 & 4.71 & 5.75 \\
\hline 81 & -19 & 10 & 1 & 180.9 & 9.55 & 4.62 & 5.66 \\
\hline 82 & -19 & 10 & 2 & 178.4 & 10.12 & 4.64 & 5.68 \\
\hline 83 & -19 & 10 & 3 & 176.5 & 10.55 & 4.68 & 5.72 \\
\hline 84 & -19 & 10 & 4 & 175.3 & 10.86 & 4.72 & 5.76 \\
\hline 85 & -19 & 10 & 5 & 174.7 & 11.03 & 4.78 & 5.82 \\
\hline 86 & -19 & 15 & 1 & 182.4 & 9.07 & 4.64 & 5.69 \\
\hline 87 & -19 & 15 & 2 & 179.5 & 9.71 & 4.67 & 5.72 \\
\hline 88 & -19 & 15 & 3 & 177.3 & 10.20 & 4.71 & 5.75 \\
\hline 89 & -19 & 15 & 4 & 175.8 & 10.54 & 4.76 & 5.81 \\
\hline 90 & -19 & 15 & 5 & 175.1 & 10.74 & 4.82 & 5.87 \\
\hline 91 & -19 & 20 & 1 & 183.5 & 8.69 & 4.66 & 5.71 \\
\hline 92 & -19 & 20 & 2 & 180.3 & 9.38 & 4.69 & 5.74 \\
\hline 93 & -19 & 20 & 3 & 177.9 & 9.92 & 4.74 & 5.78 \\
\hline 94 & -19 & 20 & 4 & 176.3 & 10.29 & 4.79 & 5.84 \\
\hline 95 & -19 & 20 & 5 & 175.5 & 10.51 & 4.86 & 5.92 \\
\hline 96 & -19 & 25 & 1 & 184.5 & 8.37 & 4.67 & 5.73 \\
\hline 97 & -19 & 25 & 2 & 181.0 & 9.11 & 4.71 & 5.76 \\
\hline 98 & -19 & 25 & 3 & 178.4 & 9.68 & 4.76 & 5.81 \\
\hline 99 & -19 & 25 & 4 & 176.6 & 10.08 & 4.82 & 5.87 \\
\hline 100 & -19 & 25 & 5 & 175.8 & 10.32 & 4.90 & 5.95 \\
\hline 101 & -18 & 5 & 1 & 178.2 & 10.59 & 4.57 & 5.60 \\
\hline 102 & -18 & 5 & 2 & 176.3 & 11.05 & 4.60 & 5.62 \\
\hline 103 & -18 & 5 & 3 & 174.8 & 11.40 & 4.62 & 5.65 \\
\hline 104 & -18 & 5 & 4 & 173.9 & 11.65 & 4.66 & 5.68 \\
\hline 105 & -18 & 5 & 5 & 173.4 & 11.79 & 4.70 & 5.73 \\
\hline 106 & -18 & 10 & 1 & 180.0 & 9.97 & 4.60 & 5.63 \\
\hline 107 & -18 & 10 & 2 & 177.5 & 10.53 & 4.63 & 5.66 \\
\hline 108 & -18 & 10 & 3 & 175.7 & 10.96 & 4.67 & 5.69 \\
\hline 109 & -18 & 10 & 4 & 174.4 & 11.27 & 4.71 & 5.74 \\
\hline 110 & -18 & 10 & 5 & 173.8 & 11.45 & 4.76 & 5.79 \\
\hline 111 & -18 & 15 & 1 & 181.3 & 9.53 & 4.62 & 5.66 \\
\hline 112 & -18 & 15 & 2 & 178.4 & 10.17 & 4.65 & 5.68 \\
\hline 113 & -18 & 15 & 3 & 176.2 & 10.66 & 4.70 & 5.72 \\
\hline 114 & -18 & 15 & 4 & 174.8 & 11.01 & 4.75 & 5.78 \\
\hline 115 & -18 & 15 & 5 & 174.1 & 11.21 & 4.81 & 5.84 \\
\hline 116 & -18 & 20 & 1 & 182.4 & 9.20 & 4.64 & 5.68 \\
\hline 117 & -18 & 20 & 2 & 179.1 & 9.89 & 4.67 & 5.71 \\
\hline 118 & -18 & 20 & 3 & 176.7 & 10.42 & 4.72 & 5.75 \\
\hline 119 & -18 & 20 & 4 & 175.1 & 10.80 & 4.78 & 5.81 \\
\hline 120 & -18 & 20 & 5 & 174.3 & 11.02 & 4.85 & 5.88 \\
\hline 121 & -18 & 25 & 1 & 183.3 & 8.91 & 4.65 & 5.69 \\
\hline 122 & -18 & 25 & 2 & 179.8 & 9.65 & 4.69 & 5.73 \\
\hline 123 & -18 & 25 & 3 & 177.1 & 10.22 & 4.74 & 5.77 \\
\hline 124 & -18 & 25 & 4 & 175.4 & 10.63 & 4.80 & 5.84 \\
\hline 125 & -18 & 25 & 5 & 174.5 & 10.86 & 4.88 & 5.92 \\
\hline
\end{tabular}

Each indicator was transformed into its variation in per unit basis through Equation (1).

$$
V_{i j}=\frac{X_{i j}-X_{j r e f}}{X_{j r e f}}
$$

where $X_{j r e f}$ is the value corresponding to criterion $j$ in the case without pre-injection. 
As indicated previously, an important step in a MCDM approach is to determine the criteria weights, and this issue will be treated in Sections 3.1-3.5. Once determined, the adequacy index for each $i$-th case, $A I_{i}$, was calculated through the SAW (simple additive weighting) method, Equation (2). Obviously, the most appropriate solution corresponds to the minimum value of $A I$.

$$
A I_{i}=\sum_{j=1}^{n} w_{j} V_{i j}
$$

where $w_{j}$ is the weight of the $j$-th criterion and $n$ the number of criteria, i.e., four $\left(\mathrm{SFC}, \mathrm{NO}_{x}, \mathrm{CO}\right.$, and $\mathrm{HC}$ ).

\subsection{Subjective Weighting Method}

In this method, the levels of importance were set by experts in the field. According to these experts, the same importance was given to consumption (50\%) and emissions (50\%). Regarding emissions, the importance was also distributed equally between $\mathrm{NO}_{\mathrm{x}}(33.3 \%), \mathrm{CO}(33 . \overline{3} \%)$, and $\mathrm{HC}(33.3 \%)$. According to this, the weights of SFC, $\mathrm{NO}_{\mathrm{x}}, \mathrm{CO}$, and $\mathrm{HC}$ result in $\mathrm{w}_{1}=0.5, \mathrm{w}_{2}=0.1 \overline{\mathrm{b}}, \mathrm{w}_{3}=0.1 \overline{\mathrm{b}}$, and $\mathrm{w}_{4}=0.1 \hat{\overline{6}}$, respectively.

\subsection{Entropy Weighting Method}

This method measures the uncertainty in the information, and the criteria weights are given by Equation (3).

$$
w_{j}=\frac{1-E_{j}}{\sum_{j=1}^{n}\left(1-E_{j}\right)}
$$

In the equation above, $1-E j$ represents the degree of diversity of the information related to the $j$-th criterion and $E_{j}$ is the entropy value of the $j$-th criterion, given by Equation (4). In this equation, $p_{i j}$ are the normalized data, Equation (5).

$$
\begin{gathered}
E_{j}=-\frac{\sum_{i=1}^{m} p_{i j} \ln \left(p_{i j}\right)}{\ln (m)} \\
p_{i j}=\frac{V_{i j}}{\sum_{i=1}^{m} V_{i j}}
\end{gathered}
$$

According to the equations above, the range of the entropy value is $0-1$. A low entropy value indicates that the degree of disorder corresponding to criterion $j$ is low and thus leads to a high weight.

\subsection{CRITIC Weighting Method}

In this method, the criteria weights are obtained by

$$
w_{j}=\frac{C_{j}}{\sum_{j=1}^{n} C_{j}}
$$

where $C_{j}$, Equation (7), represents a measure of the conflict created by criterion $j$ with respect to the decision situation defined by the rest of the criteria. As the scores of the alternatives in criteria $i$ and $j$ become more discordant, the value of $l_{i j}$ is lowered. The higher the value $C_{j}$, the larger the amount of information transmitted by the corresponding criterion and the higher the relative importance for 
the decision-making process. The objective weights are derived by normalizing these values to unity, as indicated above through Equation (6).

$$
C_{j}=\sigma_{j} \sum_{i=1}^{m}\left(1-l_{i j}\right)
$$

where $\sigma_{j}$ is the standard deviation of the $j$-th criterion and $l_{i j}$ is the correlation coefficient, Equation (8). These correlation coefficients represent linear correlation coefficients between the criteria values in the matrix.

$$
l_{i j}=\frac{\sum_{k=1}^{m}\left(V_{k i}-\bar{V}_{i}\right)\left(V_{k j}-\bar{V}_{j}\right)}{\sqrt{\sum_{k=1}^{m}\left(V_{k i}-\bar{V}_{i}\right)^{2}} \sqrt{\sum_{k=1}^{m}\left(V_{k j}-\bar{V}_{j}\right)^{2}}}
$$

\subsection{Variance Weighting Method}

The variance procedure method determines the criteria weights in terms of their statistical variances, $\sigma_{j}{ }^{2}$, through the following equation:

$$
w_{j}=\frac{\sigma_{j}^{2}}{\sum_{j=1}^{n} \sigma_{j}^{2}}
$$

\subsection{Standard Deviation Weighting Method}

The standard deviation method determines the criteria weights in terms of their standard deviations through the following equation:

$$
w_{j}=\frac{\sigma_{j}}{\sum_{j=1}^{n} \sigma_{j}}
$$

To summarize, Table 4 summarizes the criteria weights obtained using these weighting methods. As can be seen, the entropy method assigns an important weight to SFC, while the CRITIC, variance, and standard deviation methods assign $\mathrm{NO}_{x}$ as the most relevant criterion. Both variance and standard deviation procedures measure the spread, i.e., the degree to which each sample is different from the mean. As can be seen in Table 3 shown above, $\mathrm{CO}$ and $\mathrm{HC}$ emissions remain practically constant and thus lead to low values of both variance and standard deviation. On the other hand, $\mathrm{NO}_{\mathrm{x}}$ and, to a lesser extent, SFC present more spread and thus higher values of variance and standard deviation. For this reason, the variance and standard deviation methods provide a significant weight to $\mathrm{NO}_{\mathrm{x}}$ and low weights to $\mathrm{CO}$ and $\mathrm{HC}$. Since the standard deviation is the square root of the variance, the variance method assigns a higher weight to $\mathrm{NO}_{\mathrm{x}}$ than the standard deviation method. The CRITIC method assigns high values of weights to those criteria with high standard deviation and low correlation with other responses. According to this, the results obtained through the CRITIC method are very similar to those obtained through the standard deviation method, but with less differences between the criteria weights. The entropy method also takes into account the uncertainty in the information and thus assigns low weights to CO and HC. Besides uncertainty, the entropy is based on the degree of disorder and thus assigns an important weight to SFC. 
Table 4. Criteria weights according to the subjective, entropy, CRITIC, variance, and standard deviation weighting methods.

\begin{tabular}{ccccc}
\hline \multirow{2}{*}{ Weighting Method } & \multicolumn{4}{c}{ Criteria Weights, $w_{j}$} \\
\cline { 2 - 5 } & $\mathbf{S F C}(j=\mathbf{1})$ & $\mathbf{N O}_{\mathbf{x}}(\boldsymbol{j}=\mathbf{2})$ & $\mathbf{C O}(j=3)$ & $\mathbf{H C}(j=4)$ \\
\hline Subjective & 0.50 & $0.1 \hat{6}$ & $0.1 \hat{6}$ & $0.1 \hat{6}$ \\
Entropy & 0.50 & 0.19 & 0.16 & 0.14 \\
CRITIC & 0.27 & 0.41 & 0.16 & 0.16 \\
Variance & 0.09 & 0.87 & 0.02 & 0.02 \\
Standard deviation & 0.20 & 0.62 & 0.09 & 0.09 \\
\hline
\end{tabular}

Table 5 outlines the results of the 125 cases analyzed using these procedures. As can be seen, the subjective weighting method provides case 91, with an adequacy index of $A I_{91}=-0.122$, as the most appropriate injection pattern. This case corresponds to the $-19^{\circ} \mathrm{CA}$ ATDC pre-injection starting instant, $20 \%$ pre-injection rate, and $1^{\circ} \mathrm{CA}$ pre-injection duration. Since the subjective method assigns an important weight to $\mathrm{NO}_{\mathrm{x}}$, this 91st solution provides a significant $\mathrm{NO}_{\mathrm{x}}$ reduction with a low increment of SFC, CO, and HC. This solution provides an important pre-injection rate, $20 \%$, due to its importance on $\mathrm{NO}_{\mathrm{x}}$ reduction. Retarding the pre-injection instant also reduces $\mathrm{NO}_{\mathrm{x}}$ noticeably but at expenses of important increments on consumption. This reason leads to the CRITIC, variance, and standard deviation weighting methods to provide case 105 , corresponding to the $-18^{\circ} \mathrm{CA}$ ATDC pre-injection starting instant, $5 \%$ pre-injection rate, and $5^{\circ} \mathrm{CA}$ pre-injection duration, as the most appropriate injection pattern, mainly due to the important weight of $\mathrm{NO}_{\mathrm{x}}$ over the other criteria and lower weight of SFC in comparison with the subjective weighting method. A value of $-18^{\circ} \mathrm{CA}$ ATDC leads to important $\mathrm{NO}_{\mathrm{x}}$ reduction with a noticeable SFC penalty. Basically, the $\mathrm{NO}_{x}$ reduction achieved with a high pre-injection rate or by a late pre-injection rate is reached through a reduction in the combustion temperature, since the high combustion temperatures reached in the combustion chamber are responsible for most $\mathrm{NO}_{\mathrm{x}}$ emitted to the atmosphere [41,42]. On the other hand, the entropy method provides case 25 as the most appropriate injection pattern, with a $-22^{\circ} \mathrm{CA}$ ATDC pre-injection starting instant, $25 \%$ pre-injection rate, and $5^{\circ} \mathrm{CA}$ pre-injection duration. Since the entropy method assigns more weight to SFC and, to a lesser extent, to $\mathrm{NO}_{\mathrm{x}}$, it provides an earlier pre-injection starting instant, which leads to a reduction in SFC and a higher pre-injection rate, which leads to a reduction in $\mathrm{NO}_{\mathrm{x}}$.

Table 5. Adequacy index according to subjective, entropy, CRITIC, variance, and standard deviation weighting methods.

\begin{tabular}{|c|c|c|c|c|c|c|c|c|}
\hline \multirow{2}{*}{ Case (i) } & \multirow{2}{*}{$\begin{array}{c}\mathrm{S} \\
\left({ }^{\circ} \mathrm{CA} \text { ATDC }\right)\end{array}$} & \multirow{2}{*}{$\begin{array}{c}\mathrm{R} \\
(\%)\end{array}$} & \multirow{2}{*}{$\begin{array}{c}\mathrm{D} \\
\left({ }^{\circ} \mathrm{CA}\right)\end{array}$} & \multicolumn{5}{|c|}{$A I_{i}$} \\
\hline & & & & Subjective & Entropy & CRITIC & Variance & Standard Deviation \\
\hline 1 & -22 & 5 & 1 & -0.007 & -0.020 & -0.140 & -0.376 & -0.247 \\
\hline 2 & -22 & 5 & 2 & -0.006 & -0.017 & -0.128 & -0.347 & -0.227 \\
\hline 3 & -22 & 5 & 3 & -0.004 & -0.015 & -0.118 & -0.325 & -0.211 \\
\hline 4 & -22 & 5 & 4 & -0.001 & -0.012 & -0.110 & -0.309 & -0.200 \\
\hline 5 & -22 & 5 & 5 & 0.002 & -0.008 & -0.103 & -0.299 & -0.192 \\
\hline 6 & -22 & 10 & 1 & -0.004 & -0.020 & -0.170 & -0.463 & -0.302 \\
\hline 7 & -22 & 10 & 2 & -0.003 & -0.017 & -0.155 & -0.427 & -0.278 \\
\hline 8 & -22 & 10 & 3 & -0.001 & -0.014 & -0.143 & -0.399 & -0.259 \\
\hline 9 & -22 & 10 & 4 & 0.003 & -0.011 & -0.132 & -0.380 & -0.244 \\
\hline 10 & -22 & 10 & 5 & 0.007 & -0.006 & -0.124 & -0.368 & -0.235 \\
\hline 11 & -22 & 15 & 1 & -0.002 & -0.019 & -0.190 & -0.522 & -0.340 \\
\hline 12 & -22 & 15 & 2 & -0.001 & -0.017 & -0.173 & -0.482 & -0.313 \\
\hline 13 & -22 & 15 & 3 & 0.002 & -0.014 & -0.159 & -0.451 & -0.291 \\
\hline 14 & -22 & 15 & 4 & 0.006 & -0.009 & -0.148 & -0.428 & -0.274 \\
\hline 15 & -22 & 15 & 5 & 0.010 & -0.005 & -0.138 & -0.415 & -0.264 \\
\hline 16 & -22 & 20 & 1 & 0.000 & -0.019 & -0.206 & -0.569 & -0.369 \\
\hline
\end{tabular}


Table 5. Cont.

\begin{tabular}{|c|c|c|c|c|c|c|c|c|}
\hline \multirow{2}{*}{ Case (i) } & \multirow{2}{*}{$\begin{array}{c}\mathrm{S} \\
\left({ }^{\circ} \mathrm{CA} \text { ATDC }\right)\end{array}$} & \multirow{2}{*}{$\begin{array}{c}\mathbf{R} \\
(\%)\end{array}$} & \multirow{2}{*}{$\begin{array}{c}\mathrm{D} \\
\left({ }^{\circ} \mathrm{CA}\right)\end{array}$} & \multicolumn{5}{|c|}{$A I_{i}$} \\
\hline & & & & Subjective & Entropy & CRITIC & Variance & Standard Deviation \\
\hline 17 & -22 & 20 & 2 & 0.002 & -0.016 & -0.188 & -0.525 & -0.340 \\
\hline 18 & -22 & 20 & 3 & 0.004 & -0.013 & -0.172 & -0.491 & -0.316 \\
\hline 19 & -22 & 20 & 4 & 0.008 & -0.008 & -0.159 & -0.467 & -0.298 \\
\hline 20 & -22 & 20 & 5 & 0.014 & -0.003 & -0.149 & -0.452 & -0.286 \\
\hline 21 & -22 & 25 & 1 & 0.002 & -0.018 & -0.219 & -0.608 & -0.394 \\
\hline 22 & -22 & 25 & 2 & 0.004 & -0.016 & -0.199 & -0.561 & -0.362 \\
\hline 23 & -22 & 25 & 3 & 0.006 & -0.012 & -0.183 & -0.525 & -0.337 \\
\hline 24 & -22 & 25 & 4 & 0.011 & -0.007 & -0.169 & -0.499 & -0.318 \\
\hline 25 & -22 & 25 & 5 & 0.016 & -0.001 & -0.158 & -0.483 & -0.305 \\
\hline 26 & -21 & 5 & 1 & -0.010 & -0.020 & -0.112 & -0.296 & -0.195 \\
\hline 27 & -21 & 5 & 2 & -0.008 & -0.017 & -0.100 & -0.267 & -0.176 \\
\hline 28 & -21 & 5 & 3 & -0.006 & -0.015 & -0.090 & -0.245 & -0.160 \\
\hline 29 & -21 & 5 & 4 & -0.004 & -0.012 & -0.082 & -0.229 & -0.148 \\
\hline 30 & -21 & 5 & 5 & 0.000 & -0.008 & -0.075 & -0.219 & -0.141 \\
\hline 31 & -21 & 10 & 1 & -0.009 & -0.021 & -0.136 & -0.364 & -0.239 \\
\hline 32 & -21 & 10 & 2 & -0.007 & -0.018 & -0.121 & -0.329 & -0.215 \\
\hline 33 & -21 & 10 & 3 & -0.005 & -0.015 & -0.109 & -0.301 & -0.196 \\
\hline 34 & -21 & 10 & 4 & -0.002 & -0.012 & -0.098 & -0.281 & -0.181 \\
\hline 35 & -21 & 10 & 5 & 0.002 & -0.008 & -0.090 & -0.270 & -0.172 \\
\hline 36 & -21 & 15 & 1 & -0.008 & -0.021 & -0.152 & -0.411 & -0.269 \\
\hline 37 & -21 & 15 & 2 & -0.006 & -0.019 & -0.136 & -0.371 & -0.242 \\
\hline 38 & -21 & 15 & 3 & -0.004 & -0.016 & -0.121 & -0.339 & -0.220 \\
\hline 39 & -21 & 15 & 4 & 0.000 & -0.011 & -0.110 & -0.317 & -0.204 \\
\hline 40 & -21 & 15 & 5 & 0.005 & -0.007 & -0.101 & -0.304 & -0.193 \\
\hline 41 & -21 & 20 & 1 & -0.007 & -0.022 & -0.165 & -0.448 & -0.293 \\
\hline 42 & -21 & 20 & 2 & -0.005 & -0.019 & -0.147 & -0.404 & -0.263 \\
\hline 43 & -21 & 20 & 3 & -0.002 & -0.015 & -0.131 & -0.370 & -0.239 \\
\hline 44 & -21 & 20 & 4 & 0.001 & -0.011 & -0.118 & -0.346 & -0.221 \\
\hline 45 & -21 & 20 & 5 & 0.007 & -0.006 & -0.109 & -0.331 & -0.210 \\
\hline 46 & -21 & 25 & 1 & -0.006 & -0.022 & -0.175 & -0.479 & -0.312 \\
\hline 47 & -21 & 25 & 2 & -0.004 & -0.019 & -0.156 & -0.432 & -0.280 \\
\hline 48 & -21 & 25 & 3 & -0.001 & -0.015 & -0.139 & -0.395 & -0.255 \\
\hline 49 & -21 & 25 & 4 & 0.003 & -0.011 & -0.126 & -0.369 & -0.236 \\
\hline 50 & -21 & 25 & 5 & 0.008 & -0.005 & -0.115 & -0.354 & -0.224 \\
\hline 51 & -20 & 5 & 1 & -0.011 & -0.019 & -0.091 & -0.236 & -0.156 \\
\hline 52 & -20 & 5 & 2 & -0.010 & -0.017 & -0.079 & -0.207 & -0.137 \\
\hline 53 & -20 & 5 & 3 & -0.008 & -0.014 & -0.068 & -0.184 & -0.121 \\
\hline 54 & -20 & 5 & 4 & -0.005 & -0.011 & -0.060 & -0.168 & -0.109 \\
\hline 55 & -20 & 5 & 5 & -0.002 & -0.008 & -0.054 & -0.159 & -0.102 \\
\hline 56 & -20 & 10 & 1 & -0.011 & -0.021 & -0.110 & -0.290 & -0.191 \\
\hline 57 & -20 & 10 & 2 & -0.010 & -0.018 & -0.095 & -0.254 & -0.167 \\
\hline 58 & -20 & 10 & 3 & -0.007 & -0.015 & -0.083 & -0.226 & -0.148 \\
\hline 59 & -20 & 10 & 4 & -0.004 & -0.012 & -0.072 & -0.207 & -0.134 \\
\hline 60 & -20 & 10 & 5 & 0.000 & -0.008 & -0.064 & -0.195 & -0.124 \\
\hline 61 & -20 & 15 & 1 & -0.011 & -0.022 & -0.123 & -0.327 & -0.215 \\
\hline 62 & -20 & 15 & 2 & -0.010 & -0.019 & -0.107 & -0.287 & -0.188 \\
\hline 63 & -20 & 15 & 3 & -0.007 & -0.016 & -0.092 & -0.256 & -0.166 \\
\hline 64 & -20 & 15 & 4 & -0.003 & -0.012 & -0.081 & -0.233 & -0.150 \\
\hline 65 & -20 & 15 & 5 & 0.001 & -0.007 & -0.072 & -0.220 & -0.139 \\
\hline 66 & -20 & 20 & 1 & -0.011 & -0.023 & -0.134 & -0.356 & -0.234 \\
\hline 67 & -20 & 20 & 2 & -0.009 & -0.020 & -0.115 & -0.312 & -0.205 \\
\hline 68 & -20 & 20 & 3 & -0.007 & -0.016 & -0.100 & -0.278 & -0.181 \\
\hline 69 & -20 & 20 & 4 & -0.003 & -0.012 & -0.087 & -0.254 & -0.163 \\
\hline 70 & -20 & 20 & 5 & 0.003 & -0.007 & -0.077 & -0.240 & -0.151 \\
\hline 71 & -20 & 25 & 1 & -0.010 & -0.023 & -0.142 & -0.381 & -0.250 \\
\hline 72 & -20 & 25 & 2 & -0.009 & -0.021 & -0.123 & -0.334 & -0.218 \\
\hline 73 & -20 & 25 & 3 & -0.006 & -0.017 & -0.106 & -0.298 & -0.193 \\
\hline 74 & -20 & 25 & 4 & -0.002 & -0.012 & -0.093 & -0.272 & -0.174 \\
\hline 75 & -20 & 25 & 5 & 0.004 & -0.006 & -0.082 & -0.256 & -0.161 \\
\hline 76 & -19 & 5 & 1 & -0.011 & -0.018 & -0.076 & -0.195 & -0.130 \\
\hline 77 & -19 & 5 & 2 & -0.010 & -0.015 & -0.064 & -0.166 & -0.110 \\
\hline
\end{tabular}


Table 5. Cont.

\begin{tabular}{|c|c|c|c|c|c|c|c|c|}
\hline \multirow{2}{*}{ Case (i) } & \multirow{2}{*}{$\begin{array}{c}\mathrm{S} \\
\left({ }^{\circ} \mathrm{CA} \text { ATDC }\right)\end{array}$} & \multirow{2}{*}{$\begin{array}{c}\mathbf{R} \\
(\%)\end{array}$} & \multirow{2}{*}{$\begin{array}{c}\mathrm{D} \\
\left({ }^{\circ} \mathrm{CA}\right)\end{array}$} & \multicolumn{5}{|c|}{$A I_{i}$} \\
\hline & & & & Subjective & Entropy & CRITIC & Variance & Standard Deviation \\
\hline 78 & -19 & 5 & 3 & -0.008 & -0.013 & -0.054 & -0.143 & -0.094 \\
\hline 79 & -19 & 5 & 4 & -0.005 & -0.010 & -0.045 & -0.127 & -0.083 \\
\hline 80 & -19 & 5 & 5 & -0.002 & -0.007 & -0.039 & -0.118 & -0.075 \\
\hline 81 & -19 & 10 & 1 & -0.012 & -0.020 & -0.092 & -0.239 & -0.159 \\
\hline 82 & -19 & 10 & 2 & -0.010 & -0.017 & -0.077 & -0.204 & -0.135 \\
\hline 83 & -19 & 10 & 3 & -0.008 & -0.014 & -0.065 & -0.176 & -0.115 \\
\hline 84 & -19 & 10 & 4 & -0.005 & -0.011 & -0.054 & -0.156 & -0.101 \\
\hline 85 & -19 & 10 & 5 & -0.001 & -0.006 & -0.046 & -0.145 & -0.091 \\
\hline 86 & -19 & 15 & 1 & -0.012 & -0.021 & -0.103 & -0.270 & -0.179 \\
\hline 87 & -19 & 15 & 2 & -0.011 & -0.019 & -0.086 & -0.230 & -0.152 \\
\hline 88 & -19 & 15 & 3 & -0.008 & -0.015 & -0.072 & -0.199 & -0.130 \\
\hline 89 & -19 & 15 & 4 & -0.004 & -0.011 & -0.061 & -0.176 & -0.114 \\
\hline 90 & -19 & 15 & 5 & 0.000 & -0.006 & -0.052 & -0.163 & -0.103 \\
\hline 91 & -19 & 20 & 1 & -0.012 & -0.022 & -0.112 & -0.294 & -0.194 \\
\hline 92 & -19 & 20 & 2 & -0.011 & -0.019 & -0.094 & -0.251 & -0.165 \\
\hline 93 & -19 & 20 & 3 & -0.008 & -0.016 & -0.078 & -0.216 & -0.141 \\
\hline 94 & -19 & 20 & 4 & -0.004 & -0.011 & -0.065 & -0.192 & -0.123 \\
\hline 95 & -19 & 20 & 5 & 0.001 & -0.006 & -0.056 & -0.178 & -0.112 \\
\hline 96 & -19 & 25 & 1 & -0.012 & -0.023 & -0.119 & -0.315 & -0.207 \\
\hline 97 & -19 & 25 & 2 & -0.011 & -0.020 & -0.100 & -0.268 & -0.176 \\
\hline 98 & -19 & 25 & 3 & -0.008 & -0.016 & -0.083 & -0.231 & -0.151 \\
\hline 99 & -19 & 25 & 4 & -0.004 & -0.012 & -0.069 & -0.205 & -0.132 \\
\hline 100 & -19 & 25 & 5 & 0.002 & -0.006 & -0.059 & -0.190 & -0.119 \\
\hline 101 & -18 & 5 & 1 & -0.010 & -0.016 & -0.068 & -0.173 & -0.116 \\
\hline 102 & -18 & 5 & 2 & -0.009 & -0.014 & -0.056 & -0.144 & -0.096 \\
\hline 103 & -18 & 5 & 3 & -0.007 & -0.011 & -0.045 & -0.122 & -0.080 \\
\hline 104 & -18 & 5 & 4 & -0.004 & -0.008 & -0.037 & -0.106 & -0.068 \\
\hline 105 & -18 & 5 & 5 & -0.001 & -0.005 & -0.031 & -0.096 & -0.061 \\
\hline 106 & -18 & 10 & 1 & -0.011 & -0.018 & -0.082 & -0.213 & -0.141 \\
\hline 107 & -18 & 10 & 2 & -0.009 & -0.015 & -0.067 & -0.177 & -0.117 \\
\hline 108 & -18 & 10 & 3 & -0.007 & -0.012 & -0.055 & -0.150 & -0.098 \\
\hline 109 & -18 & 10 & 4 & -0.004 & -0.009 & -0.044 & -0.130 & -0.084 \\
\hline 110 & -18 & 10 & 5 & 0.001 & -0.004 & -0.036 & -0.118 & -0.074 \\
\hline 111 & -18 & 15 & 1 & -0.011 & -0.019 & -0.092 & -0.241 & -0.159 \\
\hline 112 & -18 & 15 & 2 & -0.009 & -0.016 & -0.075 & -0.200 & -0.132 \\
\hline 113 & -18 & 15 & 3 & -0.007 & -0.013 & -0.061 & -0.169 & -0.110 \\
\hline 114 & -18 & 15 & 4 & -0.003 & -0.009 & -0.049 & -0.147 & -0.094 \\
\hline 115 & -18 & 15 & 5 & 0.002 & -0.004 & -0.040 & -0.134 & -0.083 \\
\hline 116 & -18 & 20 & 1 & -0.011 & -0.020 & -0.100 & -0.262 & -0.173 \\
\hline 117 & -18 & 20 & 2 & -0.009 & -0.017 & -0.081 & -0.218 & -0.143 \\
\hline 118 & -18 & 20 & 3 & -0.007 & -0.013 & -0.066 & -0.184 & -0.120 \\
\hline 119 & -18 & 20 & 4 & -0.003 & -0.009 & -0.053 & -0.160 & -0.102 \\
\hline 120 & -18 & 20 & 5 & 0.003 & -0.004 & -0.043 & -0.146 & -0.090 \\
\hline 121 & -18 & 25 & 1 & -0.011 & -0.020 & -0.106 & -0.280 & -0.185 \\
\hline 122 & -18 & 25 & 2 & -0.009 & -0.017 & -0.087 & -0.233 & -0.153 \\
\hline 123 & -18 & 25 & 3 & -0.007 & -0.014 & -0.070 & -0.197 & -0.128 \\
\hline 124 & -18 & 25 & 4 & -0.002 & -0.009 & -0.057 & -0.171 & -0.109 \\
\hline 125 & -18 & 25 & 5 & 0.003 & -0.003 & -0.046 & -0.156 & -0.096 \\
\hline
\end{tabular}

\section{Conclusions}

The main goal of the present paper is to characterize the most appropriate pre-injection pattern in a marine diesel engine, the Wärtsilä $6 \mathrm{~L} 46$, in order to optimize the pilot injection process. A CFD model previously validated with experimental results was employed to obtain data corresponding to a set of 125 injection patterns using pilot injection. The pre-injection rate, duration, and starting instant were varied in the ranges of $5 \%$ to $25 \%, 1^{\circ}$ to $5^{\circ} \mathrm{CA}$, and $-22^{\circ}$ to $-18^{\circ} \mathrm{CA}$ ATDC, respectively. Since the manipulation of these parameters has conflicting results on consumption and emissions of $\mathrm{NO}_{\mathrm{x}}, \mathrm{CO}$, and $\mathrm{HC}$, a MCDM approach was employed to select the most appropriate injection pattern. Due to the importance of criteria weights on the overall result, several criteria weighting methods were 
compared. In particular, a subjective weighting method was compared with four objective weighting methods: entropy, CRITIC, variance, and standard deviation. The CRITIC, variance, and standard deviation methods led to the same injection pattern: $-19^{\circ} \mathrm{CA}$ pre-injection starting angle, $20 \%$ preinjection rate, and $5^{\circ} \mathrm{CA}$ pre-injection duration. Nevertheless, the entropy method provided a $-22^{\circ} \mathrm{CA}$ pre-injection starting angle, $25 \%$ pre-injection rate, and $5^{\circ} \mathrm{CA}$ pre-injection duration as the most appropriate injection pattern, and the subjective method determined this as a $-19^{\circ} \mathrm{CA}$ pre-injection starting angle, $20 \%$ pre-injection rate, and $1^{\circ} \mathrm{CA}$ pre-injection duration. The main contribution of the present work consists in emphasizing the differences between the results obtained using various methods for the determination of the criteria weights, showing the advantage of subjectivism over objectivism. Based on the overall results, the subjective method is recommended since the criteria weights are defined by experts in the field. In fact, in practical applications, subjective methods are more frequently employed than objective ones. Objective methods are only recommended when the objectivity of the research is too important or when there is no agreement between the weights proposed by the experts.

Author Contributions: Conceptualization, M.I.L. and C.G.R.; methodology, M.I.L. and C.G.R.; software, M.I.L. and C.G.R.; validation, M.I.L. and C.G.R.; formal analysis, M.I.L. and L.C.-S.; investigation, M.I.L., C.G.R., and L.C.-S.; resources, M.I.L. and C.G.R.; writing-original draft preparation, M.I.L. and L.C.-S.; writing-review and editing, M.I.L. and L.C.-S. All authors have read and agreed to the published version of the manuscript.

Funding: This research received no external funding.

Acknowledgments: The authors would like to express their gratitude to Norplan Engineering S.L. and recommend the courses "CFD with OpenFOAM" and " $\mathrm{C}++$ applied to OpenFOAM" available at www.technicalcourses.net.

Conflicts of Interest: The authors declare no conflict of interest.

\section{Nomenclature}

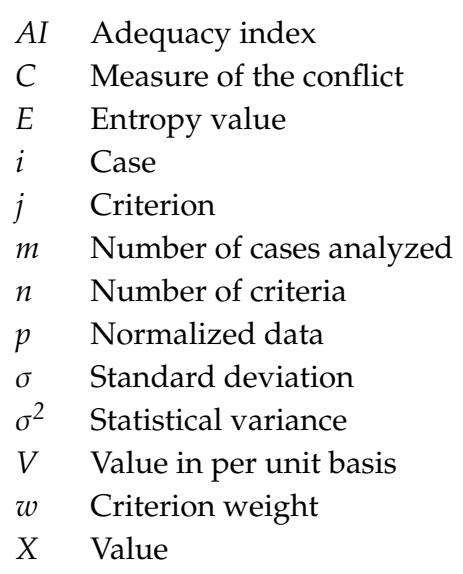

\section{Abbreviations}

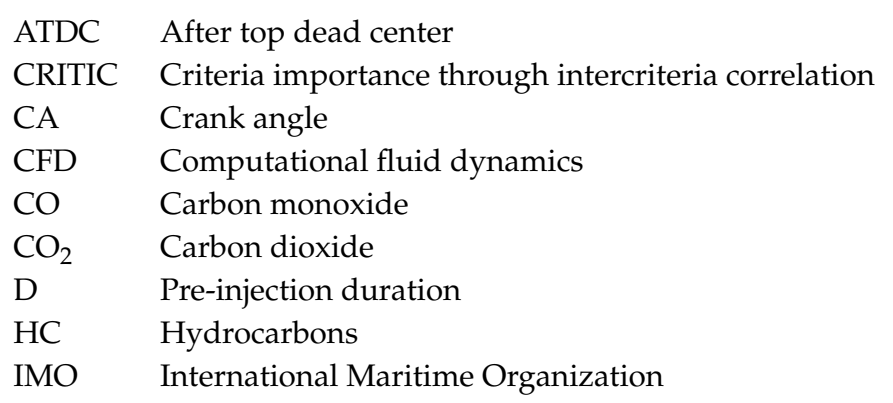




\section{References}

1. Sinay, J.; Puskar, M.; Kopas, M. Reduction of the NOx emissions in vehicle diesel engine in order to fulfill future rules concerning emissions released into air. Sci. Total Environ. 2018, 624, 1421-1428. [CrossRef] [PubMed]

2. Sui, S.; de Vos, P.; Stapersma, D.; Visser, K.; Ding, Y. Fuel consumption and emissions of ocean-going cargo ship with hybrid propulsion and different fuels over voyage. J. Mar. Sci. Eng. 2020, 8, 588. [CrossRef]

3. Perez, J.R.; Reusser, C.A. Optimization of the emissions profile of a marine propulsion system using a shaft generator with optimum tracking-based control scheme. J. Mar. Sci. Eng. 2020, 8, 221. [CrossRef]

4. Shen, H.; Zhang, J.; Yang, B.; Jia, B. Development of a marine two-stroke diesel engine MVEM with in-cylinder pressure trace predictive capability and a novel compressor model. J. Mar. Sci. Eng. 2020, 8, 204. [CrossRef]

5. Sencic, T.; Mrzljak, V.; Blecich, P.; Bonefacic, I. 2D CFD simulation of water injection strategies in a large marine engine. J. Mar. Sci. Eng. 2019, 7, 296. [CrossRef]

6. Puskar, M.; Kopas, M.; Sabadka, D.; Kliment, M.; Marieta Soltesova, M. Reduction of the gaseous emissions in the marine diesel engine using biodiesel mixtures. J. Mar. Sci. Eng. 2020, 8, 330. [CrossRef]

7. Pistek, V.; Kucera, P.; Fomin, O.; Alyona, A. Effective mistuning identification method of integrated bladed discs of marine engine turbochargers. J. Mar. Sci. Eng. 2020, 8, 379. [CrossRef]

8. Witkowski, K. Research of the effectiveness of selected methods of reducing toxic exhaust emissions of marine diesel engines. J. Mar. Sci. Eng. 2020, 8, 452. [CrossRef]

9. Seddiek, I.S.; El Gohary, M.M.; Ammar, N.R. The hydrogen-fuelled internal combustion engines for marine applications with a case study. Brodogradnja 2015, 66, 23-38.

10. El Gohary, M.M.; Ammar, N.R.; Seddiek, I.S. Steam and SOFC based reforming options of PEM fuel cells for marine applications. Brodogradnja 2015, 66, 61-76.

11. International Maritime Organization (IMO). Third IMO GHG Study 2014. Executive Summary and Final Report, MEPC 67/6/INF.3, June 2014; International Maritime Organization: London, UK, 2014.

12. Winnes, H.; Fridell, E.; Moldanova, J. Effects of marine exhaust gas scrubbers on gas and particle emissions. J. Mar. Sci. Eng. 2020, 8, 299. [CrossRef]

13. Nehmer, D.A.; Reitz, R.D. Measurement of Effect of Injection Rate and Split Injections on Diesel Engine, Soot and NOx Emissions; SAE Technical Paper 940668; SAE International: Warrendale, PA, USA, 1998. [CrossRef]

14. Han, Z.; Uludogan, A.; Hampson, G.; Reitz, R. Mechanism of Soot and NOx Emission Reduction Using Multiple-Injection in a Diesel Engine; SAE Technical Paper 960633; SAE International: Warrendale, PA, USA, 1996. [CrossRef]

15. Ikegami, M.; Nakatani, K.; Tanaka, S.; Yamane, K. Fuel Injection Rate Shaping and Its Effect on Exhaust Emissions in A Direct-Injection Diesel Engine Using a Spool Acceleration Type Injection System; SAE Techical Paper 970347; SAE International: Warrendale, PA, USA, 1997. [CrossRef]

16. Carlucci, A.P.; Ficarella, A.; Laforgia, D. Control of the combustion behaviour in a diesel engine using early injection and gas addition. Appl. Therm. Eng. 2006, 26, 2279-2286. [CrossRef]

17. Mohan, B.; Yang, W.; Chou, S.K. Fuel injection strategies for performance improvement and emissions reduction in compression ignition engines. A review. Renew. Sustain. Energy Rev. 2013, 28, 664-676. [CrossRef]

18. Chen, S.K. Simultaneous Reduction of NOx and Particulate Emissions by Using Multiple Injections in A Small Diesel Engine; SAE Technical Paper 2000-01-3084; SAE International: Warrendale, PA, USA, 2000. [CrossRef]

19. Fang, T.; Coverdill, R.; Lee, C.F.; White, R.A. Effects of injection angles on combustion process using multiple injection strategies in an HSDI diesel engine. Fuel 2008, 87, 3232-3239. [CrossRef]

20. Chen, G.; Wang, K.; Yang, J.; Zhang, W.; Xu, J.; Luo, J. Effects of fuel injection strategy with EGR on diesel engine combustion process and CDPF regeneration performance. Chin. Intern. Combust. Engine Eng. 2017, 38, 131-141. [CrossRef]

21. Cha, J.; Yang, S.H.; Naser, N.; Ichim, A.I.; Chung, S.H. High Pressure and Split Injection Strategies for Fuel Efficiency and Emissions in Diesel Engine; SAE Technical Paper 127084; SAE International: Warrendale, PA, USA, 2015. [CrossRef]

22. Shi, J.; Wang, T.; Zhao, Z.; Yang, T.; Zhang, Z. Experimental study of injection parameters on the performance of a diesel engine with Fischer-Tropsch fuel synthesized from coal. Energies 2018, 11, 3280. [CrossRef] 
23. Mardani, A.; Jusoh, A.; Zavadskas, E.K.; Cavallaro, F.; Khalifah, Z. Sustainable and renewable energy-an overview of the application of multiple criteria decision-making techniques and approaches. Sustainability 2015, 7, 13947-13984. [CrossRef]

24. Vinogradova, I.; Podvezko, V.; Zavadskas, E.K. The recalculation of the weights of criteria in MCDM methods using the Bayes approach. Symmetry 2018, 10, 205. [CrossRef]

25. Deng, H.; Yeh, C.H.; Willis, R.J. Inter-company comparison using modified TOPSIS with objective weights. Comput. Oper Res. 2000, 27, 963-973. [CrossRef]

26. Diakoulaki, D.; Mavrotas, G.; Papayannakis, L. Determining objective weights in multiple criteria problems: The critic method. Comput. Oper. Res. 1995, 22, 763-770. [CrossRef]

27. Jahan, A.; Mustapha, F.; Sapuan, S.M.; Ismail, M.Y.; Bahraminasab, M. A framework for weighting of criteria in ranking stage of material selection process. Int. J. Adv. Manuf. Tech. 2012, 58, 411-420. [CrossRef]

28. Lamas, M.I.; Rodríguez, C.G.; Rebollido, J.M. Numerical model to study the valve overlap period in the Wärtsilä 6L46 four-stroke marine engine. Pol. Marit. Res. 2012, 1, 31-37. [CrossRef]

29. Lamas, M.I.; Rodríguez, C.G. Numerical model to study the combustion process and emissions in the Wärtsilä 6L 46 four-stroke marine engine. Pol. Marit. Res. 2013, 20, 61-66. [CrossRef]

30. Lamas, M.I.; Rodriguez, C.G.; Rodriguez, J.D.; Telmo, J. Internal modifications to reduce pollutant emissions from marine engines. A numerical approach. Int. J. Nav. Archit. Mar. Eng. 2013, 5, 493-501. [CrossRef]

31. Lamas, M.I.; Rodriguez, C.G.; Telmo, J.; Rodriguez, J.D. Numerical analysis emissions from marine engines using alternative fuels. Pol. Marit. Res. 2015, 22, 48-52. [CrossRef]

32. Lamas, M.I.; Rodríguez, J.d.; Castro-Santos, L.; Carral, L.M. Effect of multiple injection strategies on emissions and performance in the Wärtsilä 6L 46 marine engine. A numerical approach. J. Clean. Prod. 2019, 206, 1-10. [CrossRef]

33. Galdo, M.I.L.; Castro-Santos, L.; Carlos, G.R.V. Selection of an appropriate pre-injection pattern in a marine diesel engine through a multiple-criteria decision making approach. Appl. Sci. 2020, 10, 2482. [CrossRef]

34. Galdo, M.I.L.; Castro-Santos, L.; Vidal, C.G.R. Numerical analysis of NOx reduction using ammonia injection and comparison with water injection. J. Mar. Sci. Eng. 2020, 8, 109. [CrossRef]

35. Ra, Y.; Reitz, R. A reduced chemical kinetic model for IC engine combustion simulations with primary reference fuels. Combust. Flame 2008, 155, 713-738. [CrossRef]

36. Yang, H.; Krishnan, S.R.; Srinivasan, K.K.; Midkiff, K.C. Modeling of NOx emissions using a superextended Zeldovich mechanism. In Proceedings of the ICEF03 2003 Fall Technical Conference of the ASME Internal Combustion Engine Division, Erie, PA, USA, 7-10 September 2003.

37. Miller, J.A.; Glarborg, P. Modeling the formation of N2O and NO2 in the thermal DeNOx process. Springer Ser. Chem. Phys. 1996, 61, 318-333.

38. Dukowicz, J.K. A particle-fluid numerical model for liquid sprays. J. Comput. Phys. 1980, 35, $229-253$. [CrossRef]

39. Ricart, L.M.; Xin, J.; Bower, G.R.; Reitz, R.D. In-Cylinder Measurement and Modeling of Liquid Fuel Spray Penetration in A Heavy-Duty Diesel Engine; SAE Technical Paper 971591; SAE International: Warrendale, PA, USA, 1997. [CrossRef]

40. Gao, J.; Kuo, T.W. Toward the accurate prediction of soot in engine applications. Int. J. Engine Res. 2018, 20, 706-717. [CrossRef]

41. Lamas, M.I.; Rodriguez, C.G. NOx reduction in diesel-hydrogen engines using different strategies of ammonia injection. Energies 2019, 12, 1255. [CrossRef]

42. Lamas, M.I.; Rodriguez, C.G. Numerical model to analyze NOx reduction by ammonia injection in diesel-hydrogen engines. Int. J. Hydrogen Energy 2017, 42, 26132-26141. [CrossRef]

Publisher's Note: MDPI stays neutral with regard to jurisdictional claims in published maps and institutional affiliations. 